\title{
New developments in the pathology of malignant lymphoma. A review of the literature published from August 2014 to October 2014
}

\author{
J. Han van Krieken
}

Published online: 20 November 2014

(C) Springer-Verlag Berlin Heidelberg 2014

\section{Introduction}

The development of technologies that enable rapid and complete genetic testing is leading to large numbers of articles and datasets with so much information that it is difficult to get a comprehensible meaning out of it. Soon we will have rather complete information on the DNA alterations of tumors, and I am confident that in the future, novel bioinformatics will enable us to use that for an individual patient, but I also believe that genetic changes do not tell the whole story. In fact, we know already that the tumor microenvironment and posttranslational alterations are very important in cancer development. This review contains several articles that deal with exactly those aspects, and they show not only their importance but also that we really need still much more information and tools to deal with them. Nevertheless, this review also contains very practical information that can be used already now, to the benefit of the patient of today.

\section{Biology of lymphoma}

Hodgkin lymphoma

Two articles give evidence for the (regulation of the) NF-kB pathway as a potential target for therapy in Hodgkin lymphoma (HL). In the tumor cells of HL, NF- $k B$, JAK/STAT and IRF4 activation enables cell survival. Although activation of

J. H. van Krieken $(\bowtie)$

Department of Pathology, Radboud University Nijmegen Medical Centre, P.O. Box 9101, 6500 HB Nijmegen, The Netherlands

e-mail: J.vankrieken@pathol.umcn.nl these pathways normally results in PRDM1 expression followed by plasma cell differentiation, HL cells never acquire a plasma cell morphology. Vogel et al. [1] show in cell lines of HL that this is the result of the downregulation of $F O X O 1$, a known tumor suppressor in HL and an intermediate factor in the forementioned process.

It is now possible to identify areas in the chromatin that are accessible, meaning that genes in those areas are potentially active. Kreher et al. [2] looked for such areas in HL and found that areas with genes that regulate interferons are especially accessible. Subsequently, they showed that interferon regulation factor 5 (IRF5) is crucial for tumor cell survival through $N F-k B$ activation.

HL cells need more than the three above-mentioned pathways, and the inflammatory infiltrate, so typical of HL, provides further support to HL neoplastic cells. According to Fhu et al. [3], the HL cells organize this at least partially themselves, by producing lymphotoxin- $\alpha$, which activates endothelial cells. The endothelial cells will then express adhesion molecules, which attract CD4-positive naive $\mathrm{T}$ cells. The $C O X 1$ pathway is the main regulator of this mechanism.

Immunohistochemistry enables us to describe protein expression in cells, but Watanabe et al. [4] give a warning: protein expression does not always mean that a protein is really active. They had found not only high BOB.1 protein expression in HL but also hypermethylation of its promoter. They reason that the expression of BOB.1 is not functional, since its function is the inducing of a B cell phenotype, which is partially lacking in HL. They hypothesize that the expression is transient and has little functional significance. I believe however that other mechanisms may diminish the effect of BOB.1 as well. The conclusion that protein expression not always indicates that a protein is effective is however well taken, and actually many examples already exist. 


\section{B cell lymphomas}

Chromosomal translocations involving the immunoglobulin genes (Ig) are a hallmark of several lymphoma types. It is assumed that most of these arise during the physiological recombination process in maturating $\mathrm{B}$ cells, but it is known that also in mature B cell lymphomas, new translocations may occur. Hu et al. [5] performed a detailed analysis of induced chromosomal changes, mainly double-strand breaks, in telangiectasia-mutated mice and discovered that in mature B cells, Ig translocations to MYC can occur in these mice, but not in wild-type mice, even in the absence of activationinduced deaminase (AID), the enzyme thought to be responsible for the physiological rearrangement process.

Development of a new lymphoma manifestation in a patient with lymphoma is generally considered to be a recurrence or a transformation. Wei et al. [6] analyzed four sets of lymphomas with discordant light or heavy chain expression with the hypothesis that these might actually be two different lymphomas in one patient. In two of the cases, they could show that the two different lymphomas indeed had a different sequence of the rearranged gene segment. This is an important topic, since the clinical situation of a recurrence rather than a new lymphoma is likely to be quite different. It remains to be shown, however, that an early precursor neoplastic B cell might actually give rise to lymphoma manifestations that are distinct even at the rearrangement level.

Muppidi et al. [7] wondered why germinal centre-derived diffuse large B cell lymphoma (GCB-DLBL) cells spread throughout the body, while normally cells with a geminal centre phenotype remain in the environment of the follicular dendritic network. Using in vivo and in vitro experiments in mice, they found that sphingosine-1-phosphate receptor-2 (S1PR2), a $\mathrm{G} \alpha 12$ and $\mathrm{G} \alpha 13$-coupled receptor, promotes growth regulation and local confinement of germinal centre B cells. Deep sequencing studies of GCB-DLBL have revealed mutations in GNA13 (encoding G $\alpha 13$ ) and S1PR2, and these mutations disrupt the migration inhibitory functions. Deficiency in $\mathrm{G} \alpha 13$, but not S1PR2, led to germinal centre B cell dissemination into lymph and blood, thus explaining the clinical manifestation of dissemination in GCB-DLBL.

Mammalian target of rapamycin (mTOR) inhibitors are of limited effect in mantle cell lymphoma (MCL), although it remains unclear why, since phosphatidylinositol-3-kinase (PI3K)/Akt/mTOR pathway activation contributes to MCL development. Rosich et al. [8] have performed a comparative analysis of the mTOR inhibitor everolimus, the pan-PI3K inhibitor NVP-BKM120 and the dual PI3K/mTOR inhibitor NVP-BEZ235 in primary MCL cells. NVP-BEZ235 was more powerful than everolimus or NVP-BKM120 in $\mathrm{PI} 3 \mathrm{~K} / \mathrm{Akt} / \mathrm{mTOR}$ signaling inhibition, indicating that targeting the $\mathrm{PI} 3 \mathrm{~K} / \mathrm{Akt} / \mathrm{mTOR}$ pathway at multiple levels is likely to be a more effective strategy for the treatment of MCL.
NVP-BEZ235 inhibited angiogenesis, migration and tumor invasiveness in MCL cells. These findings support the use of the dual PI3K/mTOR inhibitor NVP-BEZ235 as a promising approach to interfere with the microenvironment-related processes in MCL.

Sox11 is a marker for MCL and several studies indicate that Sox11-negative MCL is an indolent disease (although there is no consensus). SOX11 silencing reduces tumor growth in a MCL xenograft model and Palomero et al. [9] showed that SOX11-positive xenografts and human primary MCL tumors overexpress angiogenic gene signatures accompanied with a higher microvascular density compared with their SOX11-negative samples. Platelet-derived growth factor A (PDGFA) was overexpressed in SOX11-positive but not in SOX11-negative MCL. Imatinib, a known inhibitor of angiogenesis, impaired tumor angiogenesis and lymphoma growth in SOX11-positive MCL xenograft tumors. These findings indicate that the SOX11-PDGFA axis is a potential therapeutic target for the treatment of this aggressive disease.

Several microRNAs (miRs) are related to lymphomagenesis. Munch-Petersen et al. [10] investigated with fluorescencebased in situ hybridization (FISH) the expression of miR-21 and miR-155 in 56 cases of DLBL. MiR-155 was observed in the lymphoma cells in 19/56 (33.9\%) of the samples and miR21 was localized to the stromal compartment in $41 / 56$ (73.2 \%); a subset of these, 16/56 (28.6\%), showed labelling in lymphoma cells as well. There was no association of miR155 and miR-21 with overall survival or GCB or non-GCBlike subtypes of DLBL. The mechanism behind these findings remains unknown. Yim et al. [11] profiled the miRs in MCL before and after methylation treatment. MiR-155 showed complete methylation in one MCL cell line and 5-aza-2'deoxycytidine treatment of REC-1 led to demethylation and re-expression of miR-155-3p resulting in increased sub-G1 apoptotic cells and reduced cellular viability. In 31 primary MCL, miR-155-3p was found hypermethylated in $6(19 \%)$ cases. MiR-155-3p methylation was also hypermethylated in $66(34.6 \%)$ B cell, 24 (53\%) T cell and 6 (46\%) NK-cell lymphoma. Therefore, miR-155-3p can be considered to be a potential tumor-suppressive microRNA hypermethylated in MCL and other NHL subtypes.

Bethge et al. [12] addressed the epigenetic changes in DLBL. They describe candidate genes which were upregulated after an epigenetic treatment of B cell lymphoma cell lines (Burkitt's lymphoma (BL); follicular lymphoma (FL); DLBL both GCB and non-GCB) but that were expressed at low levels in samples from lymphoma patients. The genes LRP12 and CDH1 showed the highest methylation frequencies (94 and $92 \%$, respectively). BMPER (58\%), DUSP4 (32\%) and BMP7 (22\%) were also frequently methylated in patient samples. All these gene promoters were unmethylated in various non-malignant lymphoid control samples. LRP12 
and $C D H 1$ represent therefore promising epigenetic markers, which may be suitable for monitoring of B cell lymphoma.

\section{T cell lymphoma}

Eosinophilic granulocytes can be found in various amounts in $\mathrm{T}$ cell lymphomas, but their role remains elusive. Fredholm et al. [13] found that in mycosis fungoides (MF; $n=43$ ), the presence of eosinophilic granulocytes correlated with advanced disease stage: $78 \%$ of patients with advanced disease displayed eosinophil infiltration, whereas this was seen in only $11 \%$ of patients with patches and in $48 \%$ of those with plaque disease. Importantly, $72 \%$ of patients with positive staining for phospho-signal transducer and activator of transcription (pY-STAT3) in malignant $\mathrm{T}$ cells also stained positively for eosinophils, whereas this was only observed in $28 \%$ of pY-STAT3-negative patients. Notably, malignant T cells expressed eosinophilic activation and trafficking factors: high-mobility group BOX-1 protein (HMGB1) and interleukin 5 (IL5). These data suggest that malignant $\mathrm{T}$ cells orchestrate accumulation and activation of eosinophils supporting the notion of STAT3 being a putative target for therapy.

\section{Epidemiology of lymphoma}

Identifying the cause of disease is very instrumental in better understanding and finally better treatment. In cancer this remains however very difficult. Morton et al. [14] pooled data from 17,471 NHL cases and 23,096 controls in 20 casecontrol studies. Importantly, they linked the data not to lymphoma development in general but to the specific subtypes, which we regard as seratate disease indeed. Risks differed significantly among NHL subtypes for medical history (autoimmune diseases, hepatitis $\mathrm{C}$ virus seropositivity, eczema and blood transfusion), family history of leukaemia and multiple myeloma, alcohol consumption, cigarette smoking and certain occupations, whereas generally homogeneous risks among subtypes were observed for family history of NHL, recreational sun exposure, hay fever, allergy and socioeconomic status. Overall, the greatest difference in risk factors occurred between $\mathrm{T}$ cell and $\mathrm{B}$ cell lymphomas with increased risks generally restricted to $\mathrm{T}$ cell lymphomas for eczema, $\mathrm{T}$ cellactivating autoimmune diseases, family history of multiple myeloma and occupation as a painter. Increased risks for B cell-activating autoimmune disease and hepatitis $\mathrm{C}$ virus seropositivity and decreased risks for alcohol consumption and occupation as a teacher generally were restricted to marginal zone lymphoma, Burkitt/Burkitt-like lymphoma/leukaemia, DLBL and/or lymphoplasmacytic lymphoma. Mechanistic studies and large-scale genetic analyses might result in further clues. As the associations with familial disease indicate, germ line alterations can be relevant. Skibola et al. [15] found for instance five non-HLA loci related to susceptibility for FL (4523 case and 13,344 controls): 11q23.3 near CXCR5, $11 \mathrm{q} 24.3$ near ETS1, 3q28 in LPP, 18q21.33 near BCL2 and $8 \mathrm{q} 24.21$ near $P V T 1$. These findings further expand the number of loci associated with FL. Cerhan et al. [16] identified genetic susceptibility loci for DLBCL using data from 3857 cases to 7666 controls at $6 \mathrm{p} 25.3$, at $6 \mathrm{p} 21.33$, at $2 \mathrm{p} 23.3$ and two independent SNPs, at 8q24.21. They conclude that their data provide substantial new evidence for genetic susceptibility to DLBL. These latter studies need large international collaborations, as exemplified by the large group of authors; also very important, such a large amount of data, often referred to as "Big Data", need novel bioinformatics tools and clever (systems) biological approaches to come to a better understanding how a lymphoma develops.

A more practical approach using similar techniques is the discovery of not only risk factors but also treatment response indicators, as was taken by Liao et al. [17]. A total of 68 patients and 140 unrelated controls (note the numbers compared to the previous studies!) were genotyped for 84 singlenucleotide polymorphisms in genes encoding cytokines, chemokines and related receptors that play important roles in $\mathrm{T}$ cell-mediated gastrointestinal immunity. This focussed approach resulted in five genotypes in interleukin-22 (IL-22), namely CC at rs1179246, CC at rs2227485, AA at rs4913428, $\mathrm{AA}$ at rs1026788 and TT at rs 7314777 , that were associated with susceptibility for gastric extranodal marginal zone B cell lymphoma (ENMZL). In vitro experiments demonstrated that co-culturing peripheral mononuclear cells or CD4(+) T cells with Helicobacter pylori stimulated the secretion of IL-22 and that IL-22 induced the expression of antimicrobial proteins in gastric epithelial cells. Furthermore, patients with gastric tissue expressing IL-22 were more likely to respond to $H$. pylori eradication (14/22 vs 4/19). Because of the better knowledge of the pathogenesis of gastric ENMZL, such a hypothesisdriven approach was possible.

A single institution experience can teach us about several features of a cohort of patients. Kiesewetter et al. [18] describe their experience with 60 patients they cared for from 1999 to 2012 with an ENMZL of the ocular adnexa. They describe a highly variable treatment approach with almost half of the patients receiving systemic treatment but also nine patients who received antibiotics and six without treatment. There were no clinical features that predicted disease progression and the authors conclude that this lymphoma type has an excellent prognosis and that the least toxic individual approach should be chosen; it is however not clear on which the highly variable treatment had been based in the first place so probably we cannot learn too much from this study. Also a limited teaching value comes from the experience from $\mathrm{Lu}$ et al. [19], who retrospectively determined the presence of Epstein-Barr virus (EBV) in their cohort of 89 Taiwanese 
patients with DLBL. Using the unusual cut-off of $20 \%$ neoplastic cells that were EBER-positive, about $17 \%$ of their cases were positive; these patients had more often a non-GBC type of tumor and a poorer prognosis, which is well documented in the literature.

\section{Defining entities}

\section{B cell lymphomas}

Lee et al. [20] investigated ocular adnexal ENMZL and had six Chlamydophila psittacci (CP)-positive cases and six negative. They could determine a rather specific methylation pattern that distinguished these groups, but this is of no additional diagnostic value. Eight of their patients were treated with doxycycline (regardless of CP status) and there was also a methylation signature for responding patients, which might become a useful tool for response prediction. More precisely, their data suggest that the methylation statuses of IRAK1 and CXCL6 may reflect the response to doxycycline treatment.

Lymphoplasmacytic lymphoma (LL) presents most often as bone marrow and spleen disease and recently it has been shown to have a MYD88 mutation in almost all cases. The diagnosis of this lymphoma in a lymph node is very difficult and Hamadeh et al. [21] investigated whether the MYD88 mutation in such situations might contribute to the reliability of the diagnosis in 87 lymph node-based B cell lymphomas in the differential diagnosis of LL. They found the mutation in $9 /$ $9(100 \%)$ of lymphoplasmacytic lymphomas with classic histologic features, in 5/12 (42\%) cases that met 2008 WHO criteria for LL but with atypical morphologic features, in $3 / 15(20 \%)$ cases initially considered NMZL with plasmacytic differentiation and in 1/6 (17\%) unclassifiable splenic B cell lymphomas. The presence of MYD88 L265P was associated with IgM paraprotein. As a control, 44 splenectomy-defined splenic MZL and CLL with plasmacytic differentiation were negative for the mutation. They rereviewed their cases with knowledge of MYD88 mutation status and all available clinical features and conclude that all but one of the MYD88 mutated cases was a LL (the one exceptional case being an ENMZL). This approach suffers from a circular argument but is also inevitable. So, I would agree with their conclusion that MYD88 mutational analysis helps to better classify LL especially when presented in a lymph node.

Recently, it was discovered that hairy cell leukaemia (HCL) is characterized by a mutation in the BRAF gene, the V600E mutation. This has already resulted in a new treatment option and it is therefore increasingly important to determine the $B R A F$ status, especially in difficult cases. Although it is probably already easier and cheaper to determine mutation status by sequencing, this method is not everywhere available.
Wang et al. [22] investigated the possibility of using immunohistochemical detection of the BRAF V600E mutant in 28 FFPE tissue specimens, including HCL $(n=12)$, HCL variant (HCL-v, $n=3$ ), splenic MZL (SMZL, $n=6$ ) and other MZL $(n=7)$. Using the mouse monoclonal antibody (clone VE1, Spring Bioscience, CA) specific for BRAF V600E mutation, they found that all 12 cases of HCL showed cytoplasmic BRAF V600E protein expression, whereas all other cases were negative. Although this is still a low number of cases, others indicate that this approach is reliable.

There is a lot of attention for so-called double-hit lymphomas (DHL) after their description as a separate group in the latest WHO classification. Most commonly, these lymphomas have both a translocation in $M Y C$ and $B C L 2$. It has already been shown that other mechanisms than a translocation can result in MYC deregulation. Li et al. [23] analyzed 40 patients with what they call atypical double-hit DLBCL, nine of whom had a history of B cell non-Hodgkin lymphoma. The series included 30 DLBL, 7 B cell lymphoma, unclassifiable, with features intermediate between DLBL and BL, and 3 DLBL with coexistent follicular lymphoma. CD10, BCL2 and MYC were expressed in 28/39 (72\%), 33/35 (94\%) and 14/20 (70\%) cases, respectively. The overall survival of patients with atypical double-hit lymphoma was similar to that of patients with double-hit lymphoma and significantly worse than that of patients with DLBL with normal MYC and BCL2. In aggregate, these results support expanding the category of $M Y C / B C L 2$ DHL to include large B cell lymphomas with coexistent $M Y C$ and $B C L 2$ abnormalities other than concurrent translocations. It remains problematic how such cases are selected.

Mediastinal DLBL is a type of lymphoma with several features that are different compared to other DLBL, but the location in the mediastinum remains a cornerstone in the diagnosis. Shi et al. [24] analyzed the expression of programmed cell death 1 ligand 2 (PD-L2), which is a cell surface protein expressed by activated macrophages and dendritic cells that binds PD- 1 on T cells to inhibit immune responses. Their rationale was that amplification and/or translocations involving chromosome 9p24.1, a region that includes PDCD1LG2-encoding PD-L2, which is a common event in primary mediastinal large $\mathrm{B}$ cell lymphoma (PMBCL) but not DLBL. Twenty three of 32 (72\%) PMBCLs but only 1 of 37 (3\%) DLBCLs were positive by PD-L2 immunohistochemistry (IHC). Among PMBCLs with PDCD1LG2 CN gain, all were positive by PD-L2 IHC. One PMBCL without CN gain was positive by PD-L2 IHC. When expressed in PMBCL, PD-L2 was restricted to tumor cells and not detected on intratumoral macrophages. They conclude that PD-L2 protein is robustly expressed by the majority of PMBCLs but only rare DLBL and often associated with PDCD1LG2 copy gain. Indeed, PD-L2 IHC may serve as a useful ancillary test for distinguishing PMBCL from DLBL and for the rational selection of patients for therapeutic antibodies that inhibit PD-1 
signaling. Actually, it may now be possible to discover mediastinal DLBL localized outside the mediastinum. Gebauer et al. [25] confirm that mediastinal DLBL is indeed a separate entity, since it lacks in their 25 cases mutations present in similar lymphomas like non-GBC DLBL from nodal sites including mutations in the NF-kappa B pathway and EZH2and also MYD 88 (see above).

Because mediastinal DLBL have similarities not only with other DLBL but also with HL, Xie et al. [26] investigated FOXO1 expression (see above), which is high in B cells but low in classical Hodgkin lymphoma (cHL). Using immunohistochemistry, they showed that FOXO1 was absent or expressed at low levels in 19 of 20 primary PMBCL cases. By analyzing gene expression profiling data, $\mathrm{FOXO1}$ expression appeared to be inversely correlated with $J A K 2$ expression in these cases. FOXO1 repression might contribute to the oncogenic program and phenotype of PMBCL, a finding that also may guide therapy in the future.

As stated above, EBV-positive DLBL in the elderly has received a lot of interest. It is well known that $\mathrm{BL}$ is related to EBV as well. According to Satou et al. [27], this is also an agerelated feature. In their 33 cases of EBV-positive and 117 cases of EBV-negative sporadic (s)BL from Japan, EBV was present in higher frequencies in patients older than 50 years (48 vs. $16 \%$ ). The EBV-positive lymphomas presented more often in the tonsil, adrenal gland and cervical lymph node while the gastrointestinal tract was less frequently affected in EBV-positive sBL.

Although MYC-IGH translocations are the hallmark of BL, they are also commonly present in DLBL. According to Horn et al. [28], this is often accompanied by immunoblastic (IB) morphology. They investigated the occurrence of $M Y C$ gene rearrangements in IB-DLBL versus non-IB-DLBL using fluorescence in situ hybridization with an $M Y C$ break-apart and MYC-IGH fusion probe. In 13/39 evaluable IB-DLBLs (33\%), a translocation involving $M Y C$ was present, in contrast with only 5/68 (7\%) in the non-IB-DLBL group. The MYC rearrangement occurred as the sole translocation in the majority of cases (77\%), whereas across all DLBLs, the majority of $M Y C$ rearranged cases carry additional rearrangements of either $B C L 2$ and/or BCL6 genes (between 58 and $83 \%$ of cases). Finally, $M Y C$-rearranged IB-DLBLs were CD10-positive in $62 \%(8 / 13)$, whereas this was an uncommon feature in $M Y C$ germ line IB-DLBLs (15\%). IB-DLBLs are genetically characterized by frequent $M Y C-I G H$ translocations that often occur without additional BCL2 and/or BCL6 translocations. However, interobserver variation of IB morphology is not very good, and since IB morphology is relatively rare, still most MYCrearranged DLBL have no IB morphology.

\section{T cell lymphomas}

Morgan et al. [29] investigated whether CD103 is a good marker for intestinal enteropathy-associated T cell lymphomas
(EATL). Normal intestinal intraepithelial T lymphocytes express the $\alpha \mathrm{E}$ subunit of integrin $\alpha \mathrm{E} \beta 7$, which is detected by antibodies against CD103. In line with this, CD103 reactivity has most frequently been reported in EATL, which are postulated to arise from intestinal intraepithelial $\mathrm{T}$ lymphocytes. The authors used a newly described antibody to define the profile of CD103 immunoreactivity in paraffin sections of a wide variety of T cell neoplasms (184 cases). Overall, 22 T cell neoplasms (12\%) were CD103-positive, including 7 of 15 gastrointestinal lymphomas (3.8 \% of total cases; $46 \%$ of gastrointestinal cases). In intestinal cases, CD103 positivity did not correlate with morphology, presence or absence of enteropathy or immunohistochemical profile. A history of celiac disease was not documented in any case. Frequent but inconsistent reactivity was also noted for adult $\mathrm{T}$ cell leukaemia/lymphoma with 4 of 10 cases (40\%) positive. In the remaining $\mathrm{T}$ cell neoplasms representing most entities within the current World Health Organization classification, CD103 reactivity was sporadically observed in 11 of 159 cases $(6.9 \%)$. CD103 positivity is therefore an unusual feature in $\mathrm{T}$ cell neoplasms and tends to occur in gastrointestinal lymphomas and adult $\mathrm{T}$ cell leukaemia/lymphoma more frequently but is not a consistent characteristic of these neoplasms.

Hepatosplenic T cell lymphomas are very rare and not well characterised. Finalet Ferreiro et al. [30] performed an extensive genomic and transcriptomic analysis of six cases including one cell line. They found with comparative genomic hybridization $(\mathrm{CGH})$, a common deleted region $(\mathrm{CDR})$ at $7 \mathrm{p} 22$ and a common gained region (CGR) at 7q22. Interestingly, the CDR spans a smaller region of $13 \mathrm{Mb}$ constantly amplified in cases with a ring chromosome 7 (r7). They also found that TCRG (7p14.1) and TCRB (7q32) are involved in formation of $\mathrm{r}$, which seems to be a by-product of illegitimate somatic rearrangement of both loci. Transcriptomic analysis has not identified any CDR-related candidate tumor suppressor gene. Loss of 7p22 correlated with an enhanced expression of CHN2 (7p14.1) and the encoded $\beta 2$-chimerin. However, RNA sequencing did not identify any disease-defining mutation or gene fusion. Thus, chromosome 7 imbalances remain the only driver event detected in this tumor.

Extranodal natural killer/T cell lymphoma, nasal type (ENKTL), is a well-described lymphoma entity, but according to $\mathrm{Yu}$ et al. [31], there are three subtypes, related to three different phenotypic differentiation groups of NK/T cells. Using one nude mouse model, 2 cell lines and 16 fresh human samples, a flow cytometrical and immunohistochemical study was performed; 115 archived cases were used for confirmation. CD25 was expressed by most tumor cells in all samples, and $\mathrm{CD} 56^{+} \mathrm{CD} 25^{+}$cells were the predominant population in the mouse model, the 2 cell lines and 10 of the 16 fresh tumor samples; in the other 6 fresh tumor samples, the predominant cell population was of the $\mathrm{CD} 16^{+} \mathrm{CD} 25^{+}$phenotype and only 
a minor population showed the $\mathrm{CD} 56^{+} \mathrm{CD} 25^{+}$phenotype. According to the expression of CD56 and CD16, 115 cases could be classified into three phenotypic subtypes: $\mathrm{CD}_{6}{ }^{-} \mathrm{CD} 16^{-}, \mathrm{CD}^{-} 6^{+} \mathrm{CD} 16^{-}$and $\mathrm{CD} 56^{\mathrm{dim} /-} \mathrm{CD} 16^{+}$. Patients with tumors of the $\mathrm{CD} 56^{\mathrm{dim} /-} \mathrm{CD} 16^{+}$phenotype had a poorer prognosis than patients with tumors of the other phenotypes. Differentiation of ENKTL apparently resembles the normal natural killer cell developmental pattern, and these tumors can be classified into three phenotypic subtypes of different aggressiveness. Expression of $\mathrm{CD} 56^{\mathrm{dim} /{ }^{-}} \mathrm{CD} 16^{+}$implies a poorer prognosis.

\section{Cutaneous lymphomas}

Mycosis fungoides (MF) is the most common skin lymphoma and generally presents at middle or older age. Boulos et al. [32] collected 34 cases (out of a database with 1902) with a juvenile onset. The male to female ratio was 1.1:1. The median age of symptom onset was 9 years (range 3-19 years), with a delay in diagnosis between 1 month and 14 years. Patients primarily presented with hypopigmented $(53 \%)$, hyperpigmented (29\%) and pink-violaceous (41\%) patches/plaques. Immunohistochemistry revealed $39 \%$ with $\mathrm{CD} 8^{+}$ immunophenotype, $67 \%$ of which had hypopigmented lesions. The phototherapy response rate in 21 patients was $81 \%$. All patients who completely responded to narrowband ultraviolet B phototherapy had hypopigmented MF. They conclude that juvenile-onset MF presents with early-stage disease with an overrepresentation of hypopigmented MF and $\mathrm{CD} 8^{+}$immunophenotype. Narrowband ultraviolet $\mathrm{B}$ is an effective treatment option for juveniles, especially for those with the hypopigmented variant. This study illustrates the importance of a well-kept clinicopathologic database, so that also data on rare to very rare presentations/entities become available, which can be used when such a patient presents.

Primary cutaneous (PC)-ENKTL, is a rare Epstein-Barr virus (EBV)-associated neoplasm with poorly defined clinicopathologic features. Takata et al. [33] performed a multinational retrospective study of PC-ENKTL and CD56-positive EBV-negative peripheral $\mathrm{T}$ cell lymphoma (PC-CD56+ PTCL) in 60 cases that were divided into 51 with PCENKTL (20 of NK cell, $17 \mathrm{~T}$ cell and 14 indeterminate lineages) and 9 with PC-CD56+ PTCL. Cases of PCENKTL showed more frequent tumor necrosis, younger age and a higher frequency of CD16 and CD30 expression than cases of PC-CD56+PTCL. CD56-positive T-lineage PCENKTL tumors $(n=8)$ had more localized disease in the tumor-node-metastasis (TNM) staging and were more often of $\gamma \delta \mathrm{T}$ cell origin compared with cases of PC-CD56+PTCL $(n=9)$. PC-ENKTLs and PC-CD56+PTCLs were equally aggressive, with a 5 -year overall survival rate of $25 \%$.

As described above, MYD 88 mutation is a marker for LL, but this activating mutation is a frequent feature of primary cutaneous DLBL, leg-type (PCDLBL-LT) as well, being reported in up to $69 \%$ of the cases. Pham-Ledard et al. [34] performed a retrospective multicenter study using the medical records of patients from the French Study Group for Cutaneous Lymphomas. They had 61 patients with a diagnosis of PCDLCL-LT between 1988 and 2010 from which in 58 they could generate MYD 88 mutation status. The median age of the patients was 79 years, and $59 \%$ were female. Skin lesions were located on the leg in $76 \%$ of the cases. Thirty four of 58 patients (59 \%) harboured the MYD88 L265P mutation. Patients had similar clinical characteristics at presentation regardless of their MYD88 status, except that those harbouring the MYD 88 mutation were older and had more frequent involvement of the leg. Patients harbouring the MYD88 mutation had 3- and 5-year specific survival rates of 65.7 and 60.2 vs 85.4 and $71.7 \%$ in patients with the wild-type allele. They conclude that the MYD 88 mutation is an independent adverse prognostic factor.

\section{New entities/subtypes}

A review like this cannot be complete without a reference to IgG4 disease. Numerous IgG4 plasma cells and a high IgG4/ IgG plasma cell ratio are important criteria in the diagnosis of IgG4-related sclerosing disease (IgG4-RSD), a steroidresponsive fibroinflammatory disorder. Aggarwal et al. [35] discovered a high number of IgG4-positive plasma cells in plasma cell balanitis (PCB, previously referred to as Zoon's disease). They reviewed the clinical, histologic and immunohistochemical features of PCB in 17 patients. IgG4 counts in the areas with the greatest density varied from $1 / \mathrm{HPF}$ to $>200$ / HPF. Six of 17 (35.3\%) cases demonstrated 50 or more IgG4 plasma cells/HPF, with an $\mathrm{IgG} 4 / \mathrm{IgG}$ ratio of $>40 \%$, at least focally, in 2 of these cases. The plasma cells were clearly polytypic in $12 / 15$ evaluable cases, with an increased proportion of K-positive plasma cells in 3 ( $\geq 4$ to $5: 1$ ). None of the patients had other clinical evidence of IgG4-RSD or a lymphoproliferative disorder. In conclusion, this study demonstrates that PCB should be added to the growing list of inflammatory disorders that can have significantly increased IgG4 plasma cells but which do not represent IgG4-RSD.

CD30-positive primary cutaneous lymphoproliferative disorders are a spectrum of diseases with differing clinical presentation but overlapping histological features: lymphomatoid papulosis (LP) and primary cutaneous anaplastic large-cell lymphoma (C-ALCL). DUSP22-IRF4 locus translocation is present in $20-57 \%$ of C-ALCLs and has also been described in a series of 11 LP patients. Onaindia et al. [36] collected three cases of C-ALCL with histological features similar to the ones described in the new variant of LP with 6 p25.3 rearrangement as detected by FISH. The three cases showed 
distinctive histological and immunohistochemical features: a diffuse dermal infiltrate of atypical medium-to-large cells and marked epidermotropism with small, atypical intraepidermal lymphocytes. They conclude that their findings suggest that the presence of $6 \mathrm{p} 25.3$ rearrangement might be related to this particular biphasic pattern, but more data are actually needed.

\section{Pitfalls in lymphoma diagnosis}

Several articles, including one of my own, described the importance of review of lymphoma cases to provide an optimal diagnosis. Pongpruttipan et al. [37] describe their experience on this in Thailand. They retrieved randomly 117 lymphoma cases and gave them for review to 7 hematopathologists, members of the "Thai Hematopathologist Group," without knowing the original diagnoses. There were approximately $11 \%$ discordances between original and consensus diagnoses. DLBL had the least discordance (7\%). Small biopsies had been found to increase discordances in some lymphoma subtypes. Interestingly, everyone can review the cases, a very helpful feature of this article (http://www.diagnosticpathology.diagnomx.eu/vs/ 13000_2014_162).

Lymphoma diagnosis may be difficult in patients with Sjogren syndrome (SS). Johnsen et al. [38] included 21 SS patients with lymphoma and 28 without. There were germinal centre (GC)-like structures in 17/40 (43\%) of the patients: $4 /$ $12(33 \%)$ with and 13/28 (46\%) without lymphoma. Staining for $\mathrm{CD} 21 / \mathrm{CD} 38 / \mathrm{IgD}$ demonstrated CD21+ networks in 27/40 $(68 \%)$ of the patients. CD21+/CD38-infiltrates were seen in $25 / 40(63 \%)$ of the patients, and 16 of these were $\operatorname{IgD}+$ within the infiltrate. A monoclonal B cell population was present in $5 / 12$ patients $(42 \%)$ with and $5 / 28$ patients $(18 \%)$ without lymphoma. The authors conclude that they were unable to detect a clear association between cellular infiltrates, B cell clonality and lymphoma development. This leads to the questions which criteria had been used to make the diagnosis of lymphoma in the first place.

The diagnosis of MCL has become relatively straightforward after the introduction of cyclin D1 staining. Nevertheless, problem cases remain, which are cyclinD1-negative, but SOX11-positive. Nakashima et al. [39] assessed the performance of two commercially available monoclonal antibodies, Atlas Antibodies (Stockholm, Sweden) clone CLO142 and Cell Marque (Rocklin, CA) clone MRQ-58, for SOX11 immunohistochemistry in MCL, both cyclin D1-positive and cyclin D1-negative cases, as well as in cases of other small B cell lymphoproliferative disorders, DLBCL, BL and lymphoblastic leukaemia/lymphomas. Both antibodies showed reliable, clear nuclear staining in MCL with variable specificity. However, the MRQ-58 antibody was more specific for MCL than CLO142, which showed considerably more nonspecific staining, especially in DLBCLs (59\% positive vs.
$4 \%$ positive with MRQ-58). In addition, they reconfirmed the utility of SOX11 IHC for identifying cases of cyclin D1negative blastoid MCL. However, they also identified cases of SOX11-positive DLBCL and SMZL. They conclude that SOX11 IHC is a powerful, and relatively accessible, tool to identify MCLs with variant immunophenotypes and/or morphology, but that strict criteria need to be taken into account for interpreting SOX11 staining.

\section{Prognostic factors in lymphoma}

Grading of FL remains unreliable and other prognostic factors have been explored extensively. One of the problems of grading is the subjective nature of the evaluation, but this is also true for many of the immunohistochemical markers that have been described. Xerri et al. [40] took an interesting approach by measuring immunostainings with computerized image analysis. They showed that MUM1 is an independent, negative prognostic marker for FL using samples from two clinical trials. This approach is much better than what is used in many other studies, but the problem remains what value a prognostic indicator has in routine clinical management. Another suggestion for a prognostic marker in FL is described by Barreca et al. [41]. They applied a novel single-molecule RNA fluorescence-based in situ hybridization (FISH) technique to detect messenger RNA (mRNA) molecules of BCL2 and IgH in single cells and found marked heterogeneity in the number of BCL2 mRNA transcripts. BCL2 mRNA molecules correlated with IgH mRNA molecules in individual cells. Furthermore, a strong correlation between BCL2 and IgH protein levels was found in a series of 205 primary FL cases by flow cytometry and immunohistochemistry. They further demonstrate that BCL2 and IgH expressions determine the response to therapy in FL patients. To translate this finding into a reliable biomarker is probably very difficult.

Another lymphoma type that is difficult to manage due to unpredictable clinical behaviour is the posttransplant lymphoproliferative disease (PTLD). It is obviously a process in which the (lack of an) immune response is important. Berglund et al. [42] investigated the association between the expression of the Treg marker forkhead box protein 3 (FoxP3) in biopsies of PTLDs and survival, PTLD subtype and clinical characteristics. Using 74 cases from a population-based study, they found that most $(80 \%)$ had 29 FoxP3 cells per square millimetre (mm) or more. The amount of FoxP3 cells was not associated with the median overall survival. The FoxP3 PTLDs were more frequently of T cell phenotype, located at the graft, occurring earlier after transplantation and more likely to develop in lung recipients and in patients that had received anti-T cell globulin as induction therapy. The FoxP3 PTLDs were associated with hepatitis $\mathrm{C}$ seropositivity. These 
findings suggest that intratumoral FoxP3 Tregs do not influence survival in patients with PTLD.

MCL has a highly variable clinical course, with most patients suffering from an aggressive disease. However, in some patients, the process is actually indolent. Mahe et al. [43] investigated the expression of the ubiquitous DNA damage repair protein, poly-ADP ribose polymerase-1 (PARP1), since inhibition of PARP1 results in enhanced cytotoxicity (so-called synthetic lethality). In their series of 79 unselected cases of MCL, PARP1 expression was present in all but two cases with variable intensity. When digital $\mathrm{H}$-score analysis of PARP1 expression was performed, there was a distinct survival advantage noted in patients with lower levels of expression. These data support potential utility of PARP1 as a biomarker in MCL and for the potential use of PARP1 inhibitor-targeted therapy, so that this prognostic marker may become a predictive marker. Nygren et al. [44] describe another prognostic marker in MCL. They analyze by flow cytometry the composition of the host response. MCL cases with diffuse and nodular histological subtypes showed lower levels of $\mathrm{T}$ cells, especially CD4+ $\mathrm{T}$ cells, than those with mantle zone growth pattern. Both CD3 and CD4 levels were lower in the nodular subtype than in mantle zone and were associated with prognosis.

$B C L 2$ expression is a known negative prognostic marker in DLBL. It is well known that in FL, due to a mutation in the epitope recognized by the commonly used 124 clone antibody, BCL2 staining may give false negative results. Kendrick et al. [45] found that two alternative rabbit monoclonal antibodies (E17 and SP66) detected more often BCL2 staining in DLBL. Furthermore, using dual in situ hybridization as a new tool to detect $B C L 2$ translocation and amplification, they observed similar results as previously reported for FISH for translocation but a higher amplification frequency, indicating that $B C L 2$ amplification may be underreported in DLBL. They conclude that the accurate detection of BCL2 expression is important in the prognosis and treatment of DLBL particularly with new anti-BCL2 therapies.

Deregulation of histone $\mathrm{H} 3$ trimethylation at lysine 27 (H3K27me3) via aberration of the histone methyltransferase, enhancer of zeste homolog 2 (EZH2), has been described in DLBL. Oh et al. [46] found that a high level of H3K27me3 was present in approximately one third $(35.3 \%, 79 / 224)$ of DLBL cases, and this subset of cases was related to poor performance status, elevated lactate dehydrogenase level and a higher international prognostic index risk group. H3K27me3 level was significantly correlated with EZH2 expression and c-Myc protein expression but not correlated with $\mathrm{c}-\mathrm{Myc} / \mathrm{Bcl} 2$ coexpression or with $\mathrm{GCB}$ or non-GCB subtype. A high level of $\mathrm{H} 3 \mathrm{~K} 27 \mathrm{me} 3$ was related to an inferior overall survival and was shown to be an independent prognostic factor for overall survival along with the higher international prognostic index risk group and $\mathrm{c}-\mathrm{Myc} / \mathrm{Bcl} 2$ coexpression. Hypermethylation of DAPK1 is an independent prognostic factor predicting survival in diffuse large $B$ cell lymphoma. Many articles describe how prognostic markers retain their power in the rituximab era. Kristensen et al. [47] assessed TP53 mutation and DAPK1 methylation in 119 DLBL patients all treated with R-CHOP and found that $D A P K 1$ promoter methylation was a negative prognostic factor enhanced by P53 mutation.

Marinaccio et al. [48] took a very different approach by which they analyzed aspects of the microenvironment in DLBL. They found that CD68 and tryptase expression as well as microvascular density (MVD) were increased in chemoresistant patients when compared with chemosensitive patients. Tryptase expression showed a positive correlation with MVD, supporting a role for mast cell in DLBL tumor angiogenesis, while CD68 correlation with MVD was not significant, indicating a different role for tumor-associated macrophages (TAMs) than angiogenesis in DLBL. Although these findings are only small pieces of the large puzzle, such findings will eventually lead to a more complete understanding.

\section{Ancillary techniques}

Light chain restriction is one of the oldest ancillary techniques in diagnosing B cell lymphoma, although its usefulness is probably underestimated. An important reason is that kappa and lambda staining is not too easy on FFPE material. Since a few years a mRNA in situ hybridization (ISH) is available and Rimsza et al. [49] compared this technique with flow cytometry and immunohistochemistry. The KAPPA and LAMBDA ISH was performed on a Ventana BenchMark XT utilizing two-colour chromogenetic detection. Following optimization, they were able to visualize mRNA in benign $B$ cells in reactive tissues including germinal centre, mantle zone and postgerminal centre cells. In a series of $79 \mathrm{~B}$ cell lymphomas of various types, $39 / 79$ (49.4\%) cases were classified as KAPPA and 29/79 (36.7\%) as LAMBDA light chain restricted while 9/ $79(11.3 \%)$ cases were classified as indeterminate. Of the 70 cases with KAPPA or LAMBDA light chain restricted CISH, $69 / 70(98.6 \%)$ were concordant with the reference method, while 1/70 (1.4\%) was discordant. These are promising results although the authors erroneously use the term "clonality" instead of the more appropriate term "light chain restriction".

Zheng et al. [50] also used immunoglobulin staining for the diagnosis of lymphoma, but their approach was very unusual. They demonstrate that IgM-containing immuno complexes are differentially distributed in reactive germinal centres compared to neoplastic ones. In 25 reactive cases, IgM highlighted processes of follicular dendritic cells (FDCs), with stronger and more compact staining in light than in dark zones, and occasional very dim staining of the B cells. In FL, IgM 
expression patterns were of three types. Pattern I (38 cases) stained tumor cells within neoplastic follicles, with no staining of FDCs. Pattern II (15 cases) stained neither tumor cells nor FDCs. Pattern III (seven cases) had variable and attenuated IgM expression on FDCs with stained tumor cells in three cases. The authors suggest that a complete or considerable loss of IgM expression in FDCs, reflecting the loss of IgMcontaining ICs in FDCs, is a typical feature of FL.

Recently, several new germinal centre B cell markers were described. Menter et al. [51] stained 1590 cases (1519 on tissue microarrays, 71 on conventional slides) of variable lymphoma types. In nodular lymphocyte predominant $\mathrm{HL}$ (NLPHL), the tumor cells expressed LMO2, GCET1 and HGAL but this was only occasionally the case in HL. The majority of B cell lymphoma cases were positive for LMO2 [except for Burkitt lymphoma (BL)] and HGAL but with weaker staining intensity, compared to FL. Except for FL ( $60 \%$ of cases) and DLBCL (36 \% of cases), B cell lymphomas expressed little or no GCET1. These findings provide reference data with new potential assistance in the differential diagnosis of FL to marginal zone lymphoma (MZL), classic HL to NLPHL and primary mediastinal B cell lymphoma, DLBL to BL, and thymoma to lymphoblastic lymphoma (LBL). However, more experience is needed to confirm that these indeed provide relevant extra data compared to already available markers.

Clonality testing is an important technique in some situations, but interpretation of the results is not always straightforward. Park et al. [52] report their experience with 44/161 (27\%) B cell and 50/163 (31\%) T cell cases that contained at least one abnormal peak. They first classified the results as clonal, non-clonal or abnormal (equivocal peak on polyclonal background). Final results for all primer sets are then collectively reported as positive ( $\geq 1$ clonal result), negative (nonclonal results) or indeterminate ( $\geq 1$ abnormal result) for a clonal population. Of the cases, $29(64 \%)$ and 31 (62\%), respectively, showed clonal results in another primer set. Interobserver reproducibility was excellent for most primer sets and for final interpretations, but only fair to good for IGK V-J and TCRB D-J1+2 primer sets. These results fit well with those of the Euroclonality group and confirm the reliability of the technique, provided sufficient experience is gained.

Berget et al. [53] used clonality testing for detection of bone marrow involvement in FL. They detected involvement in $34.4 \%(33 / 96)$ of their patients. The presence of clonal rearrangements by PCR was associated with advanced clinical, high FL International Prognostic Index score and detection of bone marrow (BM) involvement by morphology and flow cytometry analysis. The patients with a polyclonal result had a poorer survival than patients. Thirteen patients who had a positive bone marrow by clonality testing but without morphologically detectable BM involvement had poorer survival than patients whereas bone marrow involvement by morphology or flow cytometry did not show a significant impact on survival. These results are counterintuitive and difficult to understand. One problem is that the clonality results were not compared to those of the FL by sequencing. Confirmation of these results is needed.

Developments in sequencing methods give us lot of new data. Using whole exome sequencing, Nakamoto-Matsubara et al. [54] had detected a G17V RHOA mutation in angioimmunoblastic $\mathrm{T}$ cell lymphoma (AILT) in $60-70 \%$ of the cases and also in peripheral $\mathrm{T}$ cell lymphomas with features of AILT, but not in other lymphomas. They now report a method based on a quantitative allele-specific PCR, which is applicable in these cases that often have a relatively low number of neoplastic cells.

\section{References}

1. Vogel MJ, Xie L, Guan H, Tooze RM, Maier T, Kostezka U, Maier HJ, Holzmann K,Chun Chan F, Steidl C, Reichel JB, Weitzer CD, Gehringer F, Kick AB, Cesarman E, Roshal M, Gascoyne RD, Möller P, Wirth T, Ushmorov A. FOXO1 repression contributes to block of plasma cell differentiation in classical Hodgkin Lymphoma. Blood. 2014 pii: blood-2014-07-590570.

2. Kreher S, Bouhlel MA, Cauchy P, Lamprecht B, Li S, Grau M, Hummel F, Köchert K, Anagnostopoulos I, Jöhrens K, Hummel M, Hiscott J, Wenzel SS, Lenz P, Schneider M, Küppers R, Scheidereit C, Giefing M, Siebert R, Rajewsky K, Lenz G, Cockerill PN, Janz M, Dörken B, Bonifer C, Mathas S. Mapping of transcription factor motifs in active chromatin identifies IRF5 as key regulator in classical Hodgkin lymphoma. Proc Natl Acad Sci U S A. 2014 pii: 201406985. [Epub ahead of print]

3. Fhu CW, Graham AM, Yap CT, Al-Salam S, Castella A, Chong SM, Lim YC. Reed Sternberg cell-derived lymphotoxin- $\alpha$ activates endothelial cells to enhance $\mathrm{T}$ cell recruitment in classical Hodgkin lymphoma. Blood. 2014. pii: blood-2014-05-576140. [Epub ahead of print]

4. Watanabe T, Kitazawa R, Mizuno Y, Kuwahara N, Ito C, Sugita A, Haraguchi R, Kitazawa S (2014) BOB.1-positive classical Hodgkin's Lymphoma carries hypermethylation of its promoter as epigenetic marker of gene-silencing memory. Acta Histochem Cytochem 47: 125-131

5. Hu J, Tepsuporn S, Meyers RM, Gostissa M, Alt FW (2014) Developmental propagation of V(D)J recombination-associated DNA breaks and translocations in mature B cells via dicentric chromosomes. Proc Natl Acad Sci U S A 111:10269-10274

6. Wei Q, Sebastian S, Papavassiliou P, Rehder C, Wang E (2014) Metachronous/concomitant B-cell neoplasms with discordant lightchain or heavy-chain isotype restrictions: evidence of distinct B-cell neoplasms rather than clonal evolutions. Hum Pathol 45:2063-2076

7. Muppidi JR, Schmitz R, Green JA, Xiao W, Larsen AB, Braun SE, An J, Xu Y, Rosenwald A, Ott G, Gascoyne RD, Rimsza LM, Campo E, Jaffe ES, Delabie J, Smeland EB, Braziel RM, Tubbs RR, Cook JR, Weisenburger DD, Chan WC, Vaidehi N, StaudtLM, Cyster JG. Loss of signalling via $\mathrm{G} \alpha 13$ in germinal centre B-cell-derived lymphoma. Nature. 2014. doi: 10.1038/nature13765. [Epub ahead of print]

8. Rosich L, Montraveta A, Xargay-Torrent S, López-Guerra M, Roldán J, Aymerich M, Salaverria I, Beà S, Campo E, Pérez-Galán 
P, Roué G, Colomer D (2014) Dual PI3K/mTOR inhibition is required to effectively impair microenvironment survival signals in mantle cell lymphoma. Oncotarget 5:6788-6800

9. Palomero J, Vegliante MC, Rodríguez ML, Eguileor A, Castellano G, Planas-Rigol E, Jares P, Ribera-Cortada I, Cid MC, Campo E, Amador V (2014) SOX11 promotes tumor angiogenesis through transcriptional regulation of PDGFA in mantle cell lymphoma. Blood 124:2235-2247

10. Munch-Petersen HD, Ralfkiaer U, Sjö LD, Hother C, Asmar F, Nielsen BS, Brown P, Ralfkiaer E, Grønbæk K. Differential expression of miR-155 and miR-21 in tumor and stroma cells in diffuse large B-cell lymphoma. Appl Immunohistochem Mol Morphol. 2014 [Epub ahead of print]

11. Lh Yim R, Wong KY, Kwong YL, Loong F, Leung CY, Chu R, Lam WW, Hui PK, Lai R, Chim CS. Methylation of miR-155-3p in mantle cell lymphoma and other non-Hodgkin's lymphomas. Oncotarget. 2014 [Epub ahead of print]

12. Bethge N, Honne H, Andresen K, Hilden V, Trøen G, Liestøl K, Holte H, Delabie J, Lind GE, Smeland EB (2014) A gene panel, including LRP12, is frequently hypermethylated in major types of Bcell lymphoma. PLoS One 9(9):e104249. doi:10.1371/journal.pone. 0104249. eCollection 2014

13. Fredholm S, Gjerdrum LM, Willerslev-Olsen A, Petersen DL, Nielsen IØ, Kauczok CS, Wobser M, Ralfkiaer U, Bonefeld CM, Wasik MA, Krejsgaard T, Geisler C, Ralfkiaer E, Gniadecki R, Woetmann A, Odum N (2014) STAT3 activation and infiltration of eosinophil granulocytes in mycosis fungoides. Anticancer Res 34: $5277-5286$

14. Morton LM, Slager SL, Cerhan JR, Wang SS, Vajdic CM, Skibola CF, Bracci PM, de Sanjosé S, Smedby KE, Chiu BC, Zhang Y, Mbulaiteye SM, Monnereau A, Turner JJ, Clavel J, Adami HO, Chang ET, Glimelius B, Hjalgrim H, Melbye M, Crosignani P, di Lollo S, Miligi L, Nanni O, Ramazzotti V, Rodella S, Costantini AS, Stagnaro E, Tumino R, Vindigni C, Vineis P, Becker N, Benavente Y, Boffetta P, Brennan P, Cocco P, Foretova L, Maynadié M, Nieters A, Staines A, Colt JS, Cozen W, Davis S, de Roos AJ, Hartge P, Rothman N, Severson RK, Holly EA, Call TG, Feldman AL, Habermann TM, Liebow M, Blair A, Cantor KP, Kane EV, Lightfoot T, Roman E, Smith A, Brooks-Wilson A, Connors JM, Gascoyne RD, Spinelli JJ, Armstrong BK, Kricker A, Holford TR, Lan Q, Zheng T, Orsi L, Dal Maso L, Franceschi S, La Vecchia C, Negri E, Serraino D, Bernstein L, Levine A, Friedberg JW, Kelly JL, Berndt SI, Birmann BM, Clarke CA, Flowers CR, Foran JM, Kadin ME, Paltiel O, Weisenburger DD, Linet MS, Sampson JN (2014) Etiologic heterogeneity among non-Hodgkin lymphoma subtypes: the InterLymph Non-Hodgkin Lymphoma Subtypes Project. J Natl Cancer Inst Monogr 48:130-144

15. Skibola CF, Berndt SI, Vijai J, Conde L, Wang Z, Yeager M, Ma B (2014) Genome-wide association study identifies five susceptibility loci for follicular lymphoma outside the HLA region. Am J Hum Genet 95:462-471

16. Cerhan JR, Berndt SI, Vijai J, Ghesquières H, McKay J, Wang SS, Wang Z, Yeager M, Conde L, de Bakker PI, Nieters A, Cox D, Burdett L, Monnereau A, Flowers CR, De Roos AJ, BrooksWilson AR, Lan Q, Severi G, Melbye M, Gu J, Jackson RD, Kane E, Teras LR, Purdue MP, Vajdic CM, Spinelli JJ, Giles GG, Albanes D, Kelly RS, Zucca M, Bertrand KA, Zeleniuch-Jacquotte A, Lawrence C, Hutchinson A, Zhi D, Habermann TM, Link BK, Novak AJ, Dogan A, Asmann YW, Liebow M, Thompson CA, Ansell SM, Witzig TE, Weiner GJ, Veron AS, Zelenika D, Tilly H, Haioun C, Molina TJ, Hjalgrim H, Glimelius B, Adami HO, Bracci PM, Riby J, Smith MT, Holly EA, Cozen W, Hartge P, Morton LM, Severson RK, Tinker LF, North KE, Becker N, Benavente Y, Boffetta P, Brennan P, Foretova L, Maynadie M, Staines A, Lightfoot T, Crouch S, Smith A, Roman E, Diver WR, Offit K, Zelenetz A, Klein RJ, Villano DJ, Zheng T, Zhang Y, Holford TR, Kricker A,
Turner J, Southey MC, Clavel J, Virtamo J, Weinstein S, Riboli E, Vineis P, Kaaks R, Trichopoulos D, Vermeulen RC, Boeing H, Tjonneland A, Angelucci E, Di Lollo S, Rais M, Birmann BM, Laden F, Giovannucci E, Kraft P, Huang J, Ma B, Ye Y, Chiu BC, Sampson J, Liang L, Park JH, Chung CC, Weisenburger DD, Chatterjee N, Fraumeni JF Jr, Slager SL, Wu X, de Sanjose S, Smedby KE, Salles G, Skibola CF, Rothman N, Chanock SJ. Genome-wide association study identifies multiple susceptibility loci for diffuse large B cell lymphoma. Nat Genet. 2014. doi: 10.1038/ ng.3105. [Epub ahead of print]

17. Liao, F., et al. Genetic polymorphisms and tissue expression of interleukin-22 associated with risk and therapeutic response of gastric mucosa-associated lymphoid tissue lymphoma. Blood cancer journal 4.10 (2014): eXX.

18. Kiesewetter B, Lukas J, Kuchar A, Mayerhoefer ME, Streubel B, Lagler H, Müllauer L, Wöhrer S, Fischbach J, Raderer M (2014) Clinical features, treatment and outcome of mucosa-associated lymphoid tissue (MALT) lymphoma of the ocular adnexa: single center experience of 60 patients. PLoS One 9(7):e104004

19. Lu CH, Lee KF, Chen CC, Chen YY, Huang CE, Tsai PS, Tsou HY, Chou HJ, Chen MF, Chen PT, Lee KD, Lung J. Clinical characteristics and treatment outcome in a Taiwanese population of patients with Epstein-Barr virus-positive diffuse large B-cell lymphoma. Jpn J Clin Oncol. 2014. pii: hyu155. [Epub ahead of print]

20. Lee MJ, Min BJ, Choung HK, Kim N, Kim YA, Khwarg SI (2014) Genome-wide DNA methylation profiles according to Chlamydophila psittaci infection and the response to doxycycline treatment in ocular adnexal lymphoma. Mol Vis 20:1037-1047

21. Hamadeh F, MacNamara SP, Aguilera NS, Swerdlow SH, Cook JR. MYD88 L265P mutation analysis helps define nodal lymphoplasmacytic lymphoma. Mod Pathol. 2014. doi: 10.1038/ modpathol.2014.120. [Epub ahead of print]

22. Wang XJ, Kim A, Li S (2014) Immunohistochemical analysis using a BRAF V600E mutation specific antibody is highly sensitive and specific for the diagnosis of hairy cell leukemia. Int J Clin Exp Pathol 7:4323-4328

23. Li S, Seegmiller AC, Lin P, Wang XJ, Miranda RN, Bhagavathi S, Medeiros LJ. B-cell lymphomas with concurrent MYC and BCL2 abnormalities other than translocations behave similarly to $\mathrm{MYC} /$ BCL2 double-hit lymphomas. Mod Pathol. 2014. doi: 10.1038/ modpathol.2014.95. [Epub ahead of print]

24. Shi M, Roemer MG, Chapuy B, Liao X, Sun H, Pinkus GS, Shipp MA, Freeman GJ, Rodig SJ. Expression of programmed cell death 1 ligand 2 (PD-L2) is a distinguishing feature of primary mediastinal (thymic) large B-cell lymphoma and associated with PDCD1LG2 copy gain. Am J Surg Pathol. 2014. [Epub ahead of print]

25. Gebauer N, Hardel TT, Gebauer J, Bernard V, Merz H, Feller AC, Thorns C (2014) Activating mutations affecting the NF-kappa B pathway and EZH2-mediated epigenetic regulation are rare events in primary mediastinal large B-cell lymphoma. Anticancer Res 34: 5503-5507

26. Xie L, Ritz O, Leithäuser F, Guan $\mathrm{H}$, Färbinger J, Weitzer $\mathrm{CD}$, Gehringer F, Bruederlein S, Holzmann K, Vogel MJ, Möller P, Wirth T, Ushmorov AC (2014) Oncotarget 5:5392-5402

27. Satou A, Asano N, Nakazawa A, Osumi T, Tsurusawa M, Ishiguro A, Elsayed AA, Nakamura N, Ohshima K, Kinoshita T, Nakamura S. Epstein-Barr virus (EBV)-positive sporadic Burkitt lymphoma: an age-related lymphoproliferative disorder? Am J Surg Pathol. 2014. [Epub ahead of print]

28. Horn H, Staiger AM, Vöhringer M, Hay U, Campo E, Rosenwald A, Ott G, Ott MM. Diffuse large B-cell lymphomas of immunoblastic type are a major reservoir for MYC-IGH translocations. Am J Surg Pathol. 2014. [Epub ahead of print]

29. Morgan EA, Pihan GA, Said JW, Yu H, Pinkus JL, Dorfman DM, Rodig SJ, Pinkus GS (2014) Profile of CD103 expression in T-cell 
neoplasms: immunoreactivity is not restricted to enteropathyassociated T-cell lymphoma. Am J Surg Pathol 38:1557-1570

30. Finalet Ferreiro J, Rouhigharabaei L, Urbankova H, van der Krogt JA, Michaux L, Shetty S, Krenacs L, Tousseyn T, De Paepe P, Uyttebroeck A, Verhoef G, Taghon T, Vandenberghe P, Cools J, Wlodarska I (2014) Integrative genomic and transcriptomic analysis identified candidate genes implicated in the pathogenesis of hepatosplenic T-cell lymphoma. PLoS One 9(7):e102977. doi:10. 1371/journal.pone.0102977. eCollection 2014

31. Yu JB, Zuo Z, Zhang WY, Yang QP, Zhang YC, Tang Y, Zhao S, Mo XM, Liu WP. Identification of immunophenotypic subtypes with different prognoses in extranodal natural killer/T-cell lymphoma, nasal type. Hum Pathol. 2014. pii: S0046-8177(14)00295-0. doi: 10.1016/j.humpath.2014.04.024.

32. Boulos S, Vaid R, Aladily TN, Ivan DS, Talpur R, Duvic M. Clinical presentation, immunopathology, and treatment of juvenile-onset mycosis fungoides: a case series of 34 patients. J Am Acad Dermatol. 2014. pii: S0190-9622(14)01780-0. doi:10.1016/j.jaad.2014.07.049. [Epub ahead of print]

33. Takata K, Hong ME, Sitthinamsuwan P, Loong F, Tan SY, Liau JY, Hsieh PP, Ng SB, Yang SF, Pongpruttipan T, Sukpanichnant S, Kwong YL, Hyeh Ko Y, Cho YT, Chng WJ, Matsushita T, Yoshino T, Chuang SS. Primary cutaneous NK/T-cell lymphoma, nasal type and CD56-positive peripheral T-cell lymphoma: a cellular lineage and clinicopathologic study of 60 patients from Asia. Am J Surg Pathol. 2014. [Epub ahead of print]

34. Pham-Ledard A, Beylot-Barry M, Barbe C, Leduc M, Petrella T, Vergier B, Martinez F, Cappellen D, Merlio JP, Grange F. High frequency and clinical prognostic value of MYD88 L265P mutation in primary cutaneous diffuse large B-cell lymphoma, leg-type. JAMA Dermatol. 2014. doi: 10.1001/jamadermatol.2014.821. [Epub ahead of print].

35. Aggarwal N, Parwani AV, Ho J, Cook JR, Swerdlow SH (2014) Plasma cell (zoon) balanitis: another inflammatory disorder that can be rich in IgG4+ plasma cells. Am J Surg Pathol 38:1437-1443

36. Onaindia A, Montes-Moreno S, Rodríguez-Pinilla SM, Batlle A, González de Villambrosía S, Rodríguez AM, Alegre V, Bermúdez GM, González-Vela C, Piris MA. Primary cutaneous anaplastic large cell lymphomas with $6 \mathrm{p} 25.3$ rearrangement exhibit peculiar histological features. Histopathology. 2014. doi: 10.1111/his.12529. [Epub ahead of print]

37. Pongpruttipan T, Sukpanichnant S, Assanasen T, Bhoopat L, Kayasut K, Kanoksil W, Wannakrairot P (2014) Interobserver variation in classifying lymphomas among hematopathologists. Diagn Pathol 9(1): 162

38. Johnsen SJ, Berget E, Jonsson MV, Helgeland L, Omdal R, Jonsson R. Evaluation of germinal center-like structures and B cell clonality in patients with primary Sjögren syndrome with and without lymphoma. J Rheumatol. 2014. pii: jrheum.131527. [Epub ahead of print]

39. Nakashima MO, Durkin L, Bodo J, Lin J, Quintanilla-Martinez L, Fu $\mathrm{K}$, Hsi ED. Utility and diagnostic pitfalls of SOX11 monoclonal antibodies in mantle cell lymphoma and other lymphoproliferative disorders. Appl Immunohistochem Mol Morphol. 2014. [Epub ahead of print]

40. Xerri L, Bachy E, Fabiani B, Canioni D, Chassagne-Clément C, Dartigues-Cuilléres P, Charlotte F, Brousse N, Rousselet MC, Foussard C, Brice P, Feugier P, Morschhauser F, Sonet A, Olive D, Salles G, LYSA study (2014) Identification of MUM1 as a prognostic immunohistochemical marker in follicular lymphoma using computerized image analysis. Hum Pathol 45:2085-2093

41. Barreca A et al (2014) Inter-and intratumoral heterogeneity of BCL2 correlates with IgH expression and prognosis in follicular lymphoma. Blood Cancer J 4(10):e249
42. Berglund D, Kinch A, Edman E, Backlin C, Enblad G, Larsson E, Molin D, Pauksens K, Sundström C, Baecklund E. Expression of intratumoral forkhead box protein 3 in posttransplant lymphoproliferative disorders: clinical features and survival outcomes. Transplantation. 2014. [Epub ahead of print]

43. Mahe E, Akhter A, Le A, Street L, Pournaziri P, Kosari F, ShabaniRad MT, Stewart D, Mansoor A. PARP1 expression in mantle cell lymphoma: the utility of PARP1 immunohistochemistry and its relationship with markers of DNA damage. Hematol Oncol. 2014. doi: 10.1002/hon.2160. [Epub ahead of print]

44. Nygren L, Wasik AM, Baumgartner-Wennerholm S, JeppssonAhlberg A, Klimkowska M, Andersson P, Buhrkuhl D, Christensson B, Kimby E, Wahlin BE, Sander B. T-cell levels are prognostic in mantle cell lymphoma. Clin Cancer Res. 2014. pii: clincanres.0889.2014. [Epub ahead of print]

45. Kendrick SL, Redd L, Muranyi A, Henricksen LA, Stanislaw S, Smith LM, Perry AM, Fu K, Weisenburger DD, Rosenwald A, Ott G, Gascoyne RD, Jaffe ES, Campo E, Delabie J, Braziel RM, Cook JR, Tubbs RR, Staudt LM, Chan WC, Steidl C, Grogan TM, Rimsza LM (2014) BCL2 antibodies targeted at different epitopes detect varying levels of protein expression and correlate with frequent gene amplification in diffuse large B-cell lymphoma. Hum Pathol 45: 2144-2153

46. Oh EJ, Yang WI, Cheong JW, Choi SE, Yoon SO (2014) Diffuse large B-cell lymphoma with histone $\mathrm{H} 3$ trimethylation at lysine 27: another poor prognostic phenotype independent of c-Myc/Bcl2 coexpression. Hum Pathol 45:2043-2050

47. Kristensen LS, Asmar F, Dimopoulos K, Nygaard MK, Aslan D, Hansen JW, Ralfkiaer E, Grønbæk K. Hypermethylation of DAPK1 is an independent prognostic factor predicting survival in diffuse large B-cell lymphoma. Oncotarget. 2014. [Epub ahead of print]

48. Marinaccio C, Ingravallo G, Gaudio F, Perrone T, Nico B, Maoirano E, Specchia G, Ribatti D. Microvascular density, CD68 and tryptase expression in human diffuse large B-cell lymphoma. Leuk Res. 2014. pii: S0145-2126(14)00284-7. doi: 10.1016/j.leukres.2014.09.007.

49. Rimsza LM, Day WA, McGinn S, Pedata A, Natkunam Y, Warnke R, Cook JR, Marafioti T, Grogan TM (2014) Kappa and lambda light chain mRNA in situ hybridization compared to flow cytometry and immunohistochemistry in B cell lymphomas. Diagn Pathol 9:144

50. Zheng Y, Zhou X, Xie J, Zhu H, Zhang S, Zhang Y, Wei X, Yue B (2014) IgM expression in paraffin sections distinguishes follicular lymphoma from reactive follicular hyperplasia. Int J Clin Exp Pathol 7:3264-3271

51. Menter T, Gasser A, Juskevicius D, Dirnhofer S, Tzankov A. Diagnostic utility of the germinal center-associated markers GCET1, HGAL, and LMO2 in hematolymphoid neoplasms. Appl Immunohistochem Mol Morphol. 2014 Sep 8. [Epub ahead of print]

52. Park IJ, Bena J, Cotta CV, Hsi ED, Jegalian AG, Rogers HJ, Tubbs RR, Wang L, Cook JR. Frequency, interobserver reproducibility and clinical significance of equivocal peaks in PCR clonality testing using Euroclonality/BIOMED-2 primers. J Clin Pathol. 2014 Sep 22. pii: jclinpath-2014-202454. doi: 10.1136/jclinpath-2014-202454.

53. Berget E, Helgeland L, Liseth K, Løkeland T, Molven A, Vintermyr OK. Prognostic value of bone marrow involvement by clonal immunoglobulin gene rearrangements in follicular lymphoma. J Clin Pathol. 2014 Sep 18. pii:jclinpath-2014-202382. doi: 10.1136/ jclinpath-2014-202382.

54. Nakamoto-Matsubara R, Sakata-Yanagimoto M, Enami T, Yoshida K, Yanagimoto S, Shiozawa Y, Nanmoku T, Satomi K, Muto H, Obara N, Kato T, Kurita N, Yokoyama Y, Izutsu K, Ota Y, Sanada M, Shimizu S, Komeno T, Sato Y, Ito T, Kitabayashi I, Takeuchi K, Nakamura N, Ogawa S, Chiba S (2014) Detection of the G17V RHOA mutation in angioimmunoblastic T-cell lymphoma and related lymphomas using quantitative allele-specific PCR. PLoS One 9(10):e109714. doi:10. 1371/journal.pone.0109714. eCollection 2014 